\title{
MATERNAL AND SEX-LINKED EFFECTS ON SIZE AND CONFORMATION IN DOMESTIC FOWL
}

\author{
A. G. COCK \\ Agricultural Research Council, Poultry Research Centre, \\ King's Buildings, Edinburgh 9 \\ and \\ J. R. MORTON \\ School of Agriculture, University of Cambridge
}

Received 8.ii.63

\section{INTRODUCTION}

Maternal effects on adult size have been reported in several species of mammal (Walton and Hammond, 1938; Hunter, 1956; Joubert and Hammond, 1958; Brumby, 1960). Their existence in birds is less certain, partly because the male (homogametic sex) is more troublesome to keep, and economically less useful, than the female. Reports on reciprocal crosses in birds have usually been confined to the female sex, where sex-linkage may mask the possible existence of true maternal effects. Yao (I96I) found evidence of maternal effects on I0-week body weight in two out of three sets of diallel crosses between inbred lines of fowl, but the effects on adult weight were insignificant. Maw (1935) and Godfrey (1953) found evidence of a major sex-linked gene affecting adult size in crosses between bantams and large breeds, and Hutt (1959) found a sex-linked dwarfing gene segregating in New Hampshires. Warren and Moore (1956) and Hutt (1962) have reported differences in adult mortality rates in reciprocal crosses between Leghorns and heavy breeds; the difference in mortality appears to be dependent on broodiness, which is well known to be inherited in a sex-linked manner. However, Moultrie, King and Cottier (1953) reported a difference in adult mortality rates (particularly from visceral lymphomatosis) in reciprocal crosses hetween two strains of White Leghorn, whose direction suggests a maternal effect, rather than sex-linkage. Allen (1962) examined this matter in more detail, using repeated backcrosses, and came to the conclusion that the difference was due to an inherited factor (a "plasmon") transmitted only through the mother. Since female offspring only were compared, the possibility that Allen's results were due to a Y-chromosomal effect cannot be excluded. Cytological evidence as to the existence or non-existence of a Y-chromosome in fowls is inconclusive. Because of uncertainty as to the number of autosomes (see van Brink, 1959) the only critical material would be meiosis in the female, which has been studied only by Miller (1938), who found no evidence of a Y-chromosome.

Variance analyses within strains, carried out in association with the 
estimation of heritability, provide the other possible source of evidence of maternal effects and sex-linkage in birds, usually through the comparison of sire and dam components of variance (S and $\mathrm{D}$ ). There are a number of difficulties in interpreting evidence of this kind:

(i) It is usually not possible, from the published data, to determine the statistical significance of differences between $\mathrm{S}$ and $\mathrm{D}$.

(ii) If female offspring only are considered, $\frac{1}{2}$ of the (additive) sex-linked variance will appear in $\mathrm{S}$, and none in $\mathrm{D}$, but in male offspring $\frac{1}{4}$ will appear in S and $\frac{1}{2}$ in D (Thomas, Blow, Cockerham and Glazener, 1958). There is no dosage compensation of sex-linked genes in the fowl (Munro, I946; Cock, I953; Siegel, Mueller and Craig, I957), so that gene effects will generally be equal in the two sexes, and the sex-linked variance will then be twice as great in males as in females. In some studies, sex of offspring has been ignored (after applying a correction for the mean sex-difference); this should therefore yield $\mathrm{S}$ and $\mathrm{D}$ each containing $\frac{1}{3}$ of the sex-linked variance.

(iii) $\mathrm{D}$ will contain the whole of the variance due to maternal and Y-chromosomal effects. In the usual hierarchical (females within males) mating scheme, $\mathrm{D}$ will also contain fractions of the variances due to autosomal dominance and epistatic effects, whereas $\mathrm{S}$ will contain no dominance variance, and small fractions only of certain types of epistatic variance (Kempthorne, 1957, pp. 421-423). Critical evidence can therefore come only from diallel matings, where S and D are equally constituted for all types of autosomal variance.

(iv) $\mathrm{S}>\mathrm{D}$ in female offspring will indicate sex-linkage unambiguously, but it will not necessarily mean that maternal effects are absent; merely that, if present, they are smaller than those due to sex-linkage. Similarly, $D>S$ does not necessarily mean that sexlinked effects are absent.

If, to these difficulties of interpretation, are added the variety of breeds and strains used, characters measured and environmental conditions found in the work of different investigators, it is perhaps not surprising that no clear overall picture of sex-linked and maternal effects can be discerned. In some instances, e.g. Brunson, Godfrey and Goodman (1956) and Goodman and Jaap (1960), the pattern of results within a single investigation is difficult to account for in view of point (ii) above. In other instances there is good agreement both within and between investigations, e.g. between El-Ibiary and Shaffner (195I), Hurry and Nordskog (1953), Wyatt (1954), Peeler, Glazener and Blow (1955), Goodman and Godfrey (I956), Hale ( $196 \mathrm{I}$ ) and Siegel ( 1962 ) (all using hierarchical matings) that $\mathrm{D}>\mathrm{S}$ for body weight at various juvenile ages. But even here, the conclusion that may be drawn-that sex-linkage is probably unimportant compared to other effects-is strictly limited. There are, on the other hand, investigations of this kind which clearly indicate sex-linked effects: by Thomas, Blow, Cockerham and Glazener (1958) for 8and ro-week body weight; by Jerome, Henderson and King (1956) 
for adult body weight, and by Lerner and Cruden (I95I) and Osborne (1954) for egg weight. The only evidence for maternal effects on characters of the adult which is at all critical appears to be that of Hazel and Lamoreux (1947) for 22-week body weight.

The results presented here for a particular pair of inbred lines show, separated from a sex-linked effect on conformation, a maternal effect on body weight that persists throughout the life of the bird.

\section{MATERIALS AND METHODS}

The inbred lines from which the data derive have been produced by regular full-sib mating (Pease and Dudley, 1954); by $195^{6}$ the $\mathbf{C}$ line had undergone 23 consecutive generations of full-sib mating, and the I line (with some early

\section{TABLE 1}

Population I ( 3 hatches): overall genotype means of females (by method of fitting constants)

\begin{tabular}{|c|c|c|c|c|c|c|c|c|}
\hline & \multicolumn{4}{|c|}{ Means } & \multirow{2}{*}{$\begin{array}{c}\text { C.V. } \\
\text { per cent. } \\
\text { within } \\
\text { sub-classes }\end{array}$} & \multicolumn{3}{|c|}{ Mean square ratios } \\
\hline & C & I & $\mathrm{C} \times \mathrm{I}$ & $\mathrm{I} \times \mathrm{C}$ & & $\begin{array}{l}\text { Inter- } \\
\text { action }\end{array}$ & Genotype & Hatch \\
\hline Body weight at ist egg & 1599 & 1288 & 1543 & 1674 & $5 \cdot 28$ & $1 \cdot 63$ & $140 \cdot 4^{* * *}$ & $7 \cdot 5^{* * *}$ \\
\hline $\begin{array}{l}\text { Body weight at } 49^{\circ} \text { days } \\
\text { (g.) }\end{array}$ & 1850 & 1326 & 1650 & 1849 & 9.71 & $0 \cdot 72$ & & $13.9^{* * *}$ \\
\hline $\begin{array}{l}\text { Tarsometatarsal length } \\
\text { (cm.) }\end{array}$ & $7 \cdot 939$ & $7 \cdot 347$ & $8 \cdot 077$ & $8 \cdot 079$ & $1 \cdot 44$ & $2 \cdot 04$ & $422 \cdot 8 * * *$ & $64: 4^{* * *}$ \\
\hline $\begin{array}{l}\text { Tarsometatarsal width } \\
(\mathrm{mm} .)\end{array}$ & $6 \cdot 776$ & 5.946 & $6 \cdot 303$ & $6 \cdot 218$ & $1 \cdot 52$ & $2 \cdot 49^{*}$ & (a) $84 \cdot 2 * * *$ & (a) $9 \cdot 9^{* *}$ \\
\hline $\begin{array}{l}\text { Days to ist egg (un- } \\
\text { weighted means of } \\
\text { hatch means) }\end{array}$ & 202.8 & 190.4 & $162 \cdot 9$ & 163.3 & $\left\{\begin{array}{r}3 \cdot 7^{2} \\
14 \cdot 6\end{array}\right.$ & $\begin{array}{c}F_{1} s \\
\text { inbreds }\end{array}$ & & \\
\hline $\begin{array}{l}\text { March egg weight (un- } \\
\text { weighted means of } \\
\text { hatch means) }\end{array}$ & $54 \cdot 1$ & $5^{1 \cdot 5}$ & $57 \cdot 2$ & $5^{8} \cdot 3$ & & & & \\
\hline Total no. of birds & 7 & $4^{1}$ & 100 & 25 & & & & \\
\hline
\end{tabular}

(a) Against interaction.

* Significant at 5 per cent. level.

** Significant at i per cent. level.

*** Significant at $0 \cdot 1$ per cent. level.

C.V. Coefficient of variation.

irregularities in mating) had undergone the equivalent of 22 generations. Data have been collected from several different populations, bred at different times and in different places, which will be designated as follows, the male parent being placed first in all crosses.

(I) Inbred parent lines and $F_{1} s$, females only, bred at the Poultry Research Field Station, Boxworth, Cambridge, 1956.

(1a) A sub-population of (I), but with males included and some surplus I and $\mathrm{C} \times \mathrm{I}$ omitted.

(2) $F_{1}$ females only, bred and reared at the Northern Poultry Breeding Station Reaseheath, Nantwich, Cheshire, and housed at Boxworth, 1953-56. 
(3) Inbred females only, bred and reared at Reaseheath, 1946-55.

(4) $F_{1}$ s and 3-way crosses, both sexes, bred and housed at Reaseheath, $195^{8}$.

(5) $F_{1} s$ and $F_{2} s$, both sexes, bred and housed at the School of Agriculture, Cambridge, 1959 .

One or more of the following measurements have been made on each population.

Body weight, measured at stated fixed ages or, in females, at the time at which each individual lays its first egg. Where, as in populations (1), (2) and (3), weight at first egg is used, comparisons of age at first egg are also given. In population (3), weight at the end of the first laying year is given; this is 308 days after each individual lays its first egg. In other populations the laying year ends at 490 days of age.

TABLE 2

Population 2 (1953-56). Weighted mean differences between reciprocal $F_{1}$ females

\begin{tabular}{|c|c|c|c|c|c|}
\hline & \multirow{2}{*}{$\begin{array}{l}\text { Overall } \\
\text { mean of } \\
\mathrm{C} \times \mathrm{I}\end{array}$} & \multirow{2}{*}{$\begin{array}{l}\text { Weighted mean } \\
\text { difference, } \\
\mathbf{I} \times \mathbf{C}-\mathbf{G} \times \mathbf{I}\end{array}$} & \multirow{2}{*}{$\begin{array}{l}\text { C.V. } \\
\text { per cent. } \\
\text { within } \\
\text { subclasses }\end{array}$} & \multicolumn{2}{|c|}{ Mean square ratios } \\
\hline & & & & Interaction & Hatches \\
\hline $\begin{array}{l}\text { Body weight at laying of } \\
\text { 1st egg } \\
\text { Body weight at } 490 \text { days } \\
\text { Age at ist egg } \\
\text { No eggs laid to } 490 \text { days } \\
\text { Number of hatches }\end{array}$ & $\begin{array}{c}1500 \mathrm{~g} . \\
1600 \mathrm{~g} . \\
169 \cdot 9 \text { days } \\
220 \cdot 1 \\
26\end{array}$ & $\begin{array}{c}+145 \pm 14 \cdot 6 \\
+83 \cdot 6 \pm 19 \cdot 4 \\
+2 \cdot 24 \pm 0 \cdot 95 \\
-9 \cdot 39\end{array}$ & $\begin{array}{l}7 \cdot 62 \\
8 \cdot 97 \\
4 \cdot 65 \\
9 \cdot 31\end{array}$ & $\begin{array}{l}0.75 \\
1 \cdot 01 \\
1 \cdot 35 \\
2 \cdot 07^{*}\end{array}$ & $\begin{array}{c}3 \cdot 38^{* * * *} \\
\\
5 \cdot 88^{* * *} \\
8 \cdot 70^{* * *} \\
2 \cdot 12^{*} \\
\text { (against } \\
\text { interaction) }\end{array}$ \\
\hline Total no. of individuals & 295 & & & & \\
\hline
\end{tabular}

* Significant at 5 per cent. level.

*** Significant at $0 \cdot 1$ per cent. level.

Tarsometatarsal length and width (mean of right and left sides), measured on the dried bones of females killed at 490 days of age. Length was measured with paralleljaw vernier calipers to $0 \cdot \mathrm{I} \mathrm{mm}$., as the distance between the furthest points of the central proximal condyle and the outer condyle of the middle digit. Width was measured with a vernier micrometer to $0.01 \mathrm{~mm}$., as the maximum (transverse) diameter at a point half-way along the bone.

Shank length (mean of right and left sides) was measured on live birds with paralleljaw vernier calipers to $0.1 \mathrm{~mm}$., in the manner described by Cock $\left(\mathrm{Ig}_{3}\right)$. Anatomically, this measurement includes tarsometatarsal length, plus the thickness of the distal end of the tibiotarsus and the overlying soft tissues.

Egg weight; this is the mean weight of the eggs laid by an individual during the entire first laying year, or during some specified shorter period.

All the populations consist of several hatches, and populations (2) and (3) extend over several years; the distribution of numbers in different hatches is nonorthogonal, sometimes severely so. All the variables are subject to hatch effects, so that exact estimates of the genotype and hatch differences demand an analysis by the method of fitting constants (Snedecor, 1946, p. 296), the validity of which will depend on the genotype-hatch interaction being negligible. Analyses of this kind have been carried out on population ( 1 ), but in all other populations comparisons have been restricted to two groups at a time, thus enabling the simpler method of the weighted mean difference (Snedecor, 1946, p. 289) to be used to eliminate hatch effects. The sexes were generally reared separately, and so require separate analyses. 


\section{RESULTS}

The existence of a reciprocal difference was first noted in population ( $\mathrm{I} a) ; \mathrm{I} \times \mathrm{C}$ females were found to be heavier than $\mathrm{C} \times \mathrm{I}$ at all ages from hatching to 20 weeks and beyond. The difference at 20 weeks is $93.9 \pm 18.3$ g., or 7.1 per cent. of the mean weight of $\mathrm{C} \times \mathrm{I}$; the percentage difference remains approximately constant at different ages. In males, however, the difference is small and insignificant $(19.9 \pm 19.9 \mathrm{~g}$. at 20 weeks, or 0.9 per cent. of $\mathrm{C} \times \mathrm{I})$. The results for females were confirmed with larger numbers in populations (I) and (2): see tables I and 2. Population (2) is particularly convincing; the data cover 26 hatches spread over 4 years, and the $\mathrm{I} \times \mathrm{C}-\mathrm{C} \times \mathrm{I}$ difference in weight at first egg is positive in every hatch; the weighted mean difference agrees well with that derived from population ( $\mathrm{I} a$ ). There is a significant difference in age at first egg, but this is far too small to have an appreciable effect on the body weight.

At first sight it appears in population (2) that by 490 days of age the reciprocal difference in weight has been reduced to little more than half its value at first egg. However, the two populations are not based on the same number of birds, since some died during the laying year. In addition, a few birds actually lost weight during the laying year; these presumably were in poor health or undergoing a moult when weighed at $49^{\circ}$ days. If birds dying or losing weight are omitted throughout, the weighted mean differences become $127.6 \mathrm{~g}$. (at first egg) and $122 \cdot 2 \mathrm{~g}$. (at 490 days). An interesting peculiarity of population (2) is the existence of a significant genotype $\times$ hatch interaction in number of eggs laid. Most of this interaction is due to an effect of late versus early hatches on the reciprocal difference. If hatched before 20th March, $\mathrm{C} \times$ Is average 19.5 eggs more than contemporary $\mathrm{I} \times \mathrm{Cs}$; if hatched after that date, they average only $3 \cdot 1$ eggs more. An examination of individual laying records shows that this interaction is due to a greater tendency for $\mathrm{I} \times \mathrm{C}$ birds to undergo a partial moult at the end of autumn, with a consequent gap in egg-production (the so-called "winter pause"). In late hatches the birds have just come into lay at the critical season, and few birds of either cross undergo a winter pause.

Several other pairs of reciprocal $F_{1}$ crosses were included in population (2); the results from these are shown in table 3 . These data afford four indirect estimates of the $\mathrm{I} \times \mathrm{C}-\mathrm{C} \times \mathrm{I}$ difference; two of these (via W and $\mathrm{P}$ ) agree well with the direct estimate; the other two agree less well, but it must be remembered that all these indirect estimates are subject to large standard errors.

The rather scanty data on the $\mathrm{C}$ line in population ( $\mathrm{I}$ ) have been augmented by data from population (3) (table 4). The difference in weight at first egg between $\mathrm{C}$ and $\mathrm{I}$ is only about twice as great as the difference between reciprocal $F_{1}$ females; by this standard the reciprocal difference is a very large one. The figures in table 4 are unweighted averages of yearly means, as there is for all characters 
a significant year $\times$ line interaction (possibly due to uneven distribution of the lines between hatches within years).

TABLE 3

Population 2 (1953-56). Weighted mean differences (body weight at first egg) between reciprocal $F_{1}$ females

\begin{tabular}{|c|c|c|c|c|}
\hline & & $\begin{array}{l}\text { No. of } \\
\text { hatches }\end{array}$ & $\begin{array}{l}\text { Total no. of } \\
\text { birds }\end{array}$ & \\
\hline $\begin{array}{l}\mathbf{I} \times \mathbf{W}-\mathbf{W} \times \mathbf{I} \quad \cdot \\
\mathbf{C} \times \mathbf{W}-\mathbf{W} \times \mathbf{C} \quad: \\
\mathbf{I} \times \mathbf{M}-\mathbf{M} \times \mathbf{I} \\
\mathbf{C} \times \mathbf{M}-\mathbf{M} \times \mathbf{C} \quad:\end{array}$ & 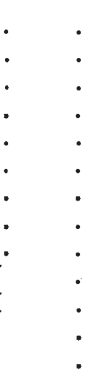 & $\begin{array}{r}9 \\
15 \\
11 \\
18 \\
8 \\
8 \\
12 \\
24 \\
26\end{array}$ & $\begin{array}{r}6 \mathrm{r} \\
109 \\
64 \\
138 \\
59 \\
6 \mathrm{r} \\
87 \\
229 \\
295\end{array}$ & $\begin{array}{l}+61 \cdot 9 \\
-54 \cdot 2 * \\
+17 \cdot 5 \\
-19 \cdot 6 \\
+160 \cdot 5^{* * *} \\
+52 \cdot 1 \\
+36 \cdot 0 \\
-40 \cdot 6 * \\
+145 \cdot 3^{* * *} \\
+116 \cdot 1 \\
+37 \cdot 2 \\
+108 \cdot 4 \\
+76 \cdot 6\end{array}$ \\
\hline
\end{tabular}

I, $C$ and $W$ are inbred lines of White Leghorn; $M, P$ and $Q$ are inbred lines of Rhode Island Red. The $F_{1}$ having the larger line as $q$ parent is in all cases placed first.

* Significant at 5 per cent. level.

*** Significant at $0 \cdot 1$ per cent. level.

TABLE 4

Population 3 (1946-55). Unweighted averages of yearly means

\begin{tabular}{|c|c|c|c|c|c|c|}
\hline & \multicolumn{3}{|c|}{ C 우우 } & \multicolumn{3}{|c|}{ I 우요 } \\
\hline & $\begin{array}{l}\text { Total } \\
\text { no. of } \\
\text { records }\end{array}$ & Mean & $\begin{array}{c}\text { Mean square } \\
\text { (within } \\
\text { years) }\end{array}$ & $\begin{array}{l}\text { Total } \\
\text { no. of } \\
\text { records }\end{array}$ & Mean & $\begin{array}{l}\text { Mean square } \\
\text { (within } \\
\text { years) }\end{array}$ \\
\hline (a) Body weight at laying of & 334 & $1592 \mathrm{~g}$. & 15,857 & $3^{12}$ & $1368 \mathrm{~g}$. & 12,570 \\
\hline $\begin{array}{l}\text { (b) Body weight after } 44 \\
\text { weeks laying }\end{array}$ & 251 & $1580 \mathrm{~g}$ & 34,182 & 254 & $1264 \mathrm{~g}$ & 22,528 \\
\hline No. of years in which $(b)<(a)$ & $\ldots$ & $\begin{array}{c}6 / 10 \\
250 \text { days }\end{array}$ & $\cdots$ & $\ldots$ & $\begin{array}{l}9 / 10 \\
202 \text { days }\end{array}$ & $\ldots$ \\
\hline $\begin{array}{l}\text { Egg production in } 44 \text { weeks } \\
\text { (from laying of ist egg) }\end{array}$ & 259 & 112 eggs & 910 & $\begin{array}{l}312 \\
256\end{array}$ & I 3 eggs & $\begin{array}{l}1,103 \\
1,004\end{array}$ \\
\hline Mean egg weight & 258 & $54.7 \mathrm{~g}$. & $3 \cdot 777$ & 256 & $49 \cdot 7 \mathrm{~g}$. & 3.865 \\
\hline
\end{tabular}

Calculated from: F. J. Dudley (1957), "The Inbred Lines of White Leghorns and Rhode Island Red Poultry at Reaseheath", A.R.C. Circular Parts I and II. No. 593/57.

The data so far, in that they show a reciprocal difference in females but not in males, suggest sex-linkage rather than a maternal effect. Population (4), consisting of $F_{1} s$ and crosses of the $F_{1}$ females to a 
third line $(W)$, was produced to enlarge the $F_{1}$ data, and to show whether the gene or genes for increased size were carried on the $\mathrm{X}$-chromosome of the smaller I line, or, as the evidence for the absence of a $\mathrm{Y}$-chromosome in fowls is inconclusive, on the $\mathrm{Y}$-chromosome of the $\mathrm{C}$ line. The effects estimated by the different comparisons,

TABLE 5

Population 4. Weighted mean differences in body weight between reciprocal crosses

\begin{tabular}{|c|c|c|c|c|c|c|c|c|}
\hline \multirow{3}{*}{$\begin{array}{c}\begin{array}{c}\text { Effect } \\
\text { estimated }\end{array} \\
\text { Age (weeks) }\end{array}$} & \multicolumn{4}{|c|}{$\mathrm{I} \times \mathrm{C}-\mathrm{C} \times \mathrm{I}$} & \multicolumn{4}{|c|}{$\mathrm{W} \times(\mathrm{I} \times \mathrm{C})-\mathrm{W} \times(\mathrm{C} \times \mathrm{I})$} \\
\hline & \multicolumn{2}{|c|}{$\stackrel{0}{a}$} & \multicolumn{2}{|c|}{$M-\stackrel{\text { 우 }}{X}+r$} & \multicolumn{2}{|c|}{$\sigma_{m \rightarrow X}^{a}$} & \multicolumn{2}{|c|}{$\stackrel{\text { 우 }}{m+r}$} \\
\hline & g. & $\begin{array}{c}\text { as } \% \text { of } \\
\mathrm{C} \times \mathrm{I}\end{array}$ & g. & $\begin{array}{c}\text { as } \% \text { of } \\
\mathrm{C} \times \mathrm{I}\end{array}$ & g. & $\begin{array}{c}\text { as } \% \text { of } \\
W \times \\
(\mathrm{C} \times I)\end{array}$ & g. & $\begin{array}{c}\text { as } \% \text { of } \\
\underset{\mathrm{W}}{\times} \\
(\mathrm{C} \times \mathrm{I})\end{array}$ \\
\hline $\begin{array}{c}\text { Egg } \dagger \\
0 \\
4 \\
8 \\
12 \\
20\end{array}$ & $\begin{array}{r}+8.22 \\
+2.22 \\
+22.03 \\
+62.01 \\
+90.48 \\
+100.32 \\
\pm 16.19\end{array}$ & $\begin{array}{r}+17.10 \\
+6.23 \\
+8.70 \\
+9.06 \\
+8.25 \\
+5.92 \\
\pm 0.97\end{array}$ & $\begin{array}{r}+8.22 \\
+3.91 \\
+42.91 \\
+92.26 \\
+110.23 \\
+117.14 \\
+11.22\end{array}$ & $\begin{array}{c}+17.10 \\
+11.84 \\
+21.07 \\
+18.11 \\
+13.52 \\
+9.00 \\
\pm 0.86\end{array}$ & $\begin{array}{r}+0.27 \\
+0.19 \\
+5.49 \\
+14.81 \\
+34.05 \\
+11.96 \\
+48.37\end{array}$ & $\begin{array}{l}+0.43 \\
+0.46 \\
+0.93 \\
+2.04 \\
+2.74 \\
+0.96 \\
+2.83^{*}\end{array}$ & $\begin{array}{c}+0.27 \\
+0.16 \\
-1.53 \\
-6.83 \\
-8.63 \\
\pm 7.69 \\
-15.25^{*}\end{array}$ & $\begin{array}{l}+0.43 \\
+0.40 \\
-0.60 \\
-1.10 \\
-0.89 \\
\pm 0.79 \\
-0.99\end{array}$ \\
\hline $\begin{array}{l}\text { No. hatches } \\
\text { Total no. birds }\end{array}$ & $\begin{array}{r}5 \\
9^{\circ}\end{array}$ & & 9 & & 2 & & & $\begin{array}{l}4 \\
3\end{array}$ \\
\hline
\end{tabular}

All comparisons are homogeneous between hatches, except for $F_{1}$ females at 4 and 8 weeks (heterogeneous at 5 per cent. level) and at o weeks (heterogeneous at 1 per cent. level).

$M=$ effect of substituting a $\mathrm{C}$ for an I maternal environment.

$m=$ effect of substituting an $\mathrm{I} \times \mathrm{C}$ for a $\mathrm{C} \times \mathrm{I}$ maternal environment.

$X=$ effect of substituting a $\mathrm{C}$ for an I X-chromosome.

$\boldsymbol{r}=$ effect of substituting a $\mathrm{C}$ for an I Y-chromosome.

* Based on one hatch only.

$\uparrow$ Based on mean weight of all eggs laid during the total hatching period.

and the results, are shown in table 5. It is clear that there is a reciprocal difference in $\mathbf{F}_{1}$ males, and that the original small sample in population ( $\mathrm{a} a$ ) was misleading in this respect. The difference in males is smaller than that in females; not significantly smaller in absolute terms, but significantly smaller if taken as a percentage of the mean weight of $\mathrm{C} \times \mathrm{I}$. The results of a direct solution of the equations at the top of table 5 for $M, X, m$ and $Y$ (involving only the assumption that the effects are additive on a percentage scale) are shown on the left of table 7 ; it will be seen that $X$ is negative, whereas both $m$ and $r$ are small and quite insignificant. If we assume that $m$ and $Y$ are both zero, we may obtain two independent estimates of $X$; these 
are shown on the right of table 7. The two estimates are in excellent agreement, and show that $X$ has a value of about -3 per cent., i.e. the smaller I line has the "larger" X-chromosome. Thus about one-third of the difference between reciprocal $F_{1}$ females is due to this "negative" sex-linkage, and two-thirds to a maternal effect. On a percentage basis, the difference between the $\mathrm{W}$-cross males increases slowly but steadily with age, suggesting that the $X$ effects act as a difference in specific growth rate. In the $F_{1} s$, on the other hand, particularly in the females, the difference, as a percentage, is higher at 4 and 8 weeks than either before or after. The figures for the earlier ages for $F_{1}$ females may, however, be misleading, since there is significant heterogeneity between hatches in the $F_{1}$ females at 0,4 and 8 weeks, due to an unusually large difference in one hatch. If this exceptional hatch is omitted the percentage difference remains more nearly constant with age. In population ( $1 a$ ) the difference between $F_{1}$ females varies (irregularly and insignificantly) only between $7 \cdot 1$ and 10.6 per cent. in the period from I to 20 weeks. The effect $M$ thus appears, in contrast to $X$, to be something already developed in the embryo, which is maintained proportionately more or less constant, but possibly with some diminution, during postnatal growth.

The tarsometatarsi of population (I) had been kept with the intention of obtaining a more reliable measure of adult size than is afforded by body weight, but when they were measured it became clear (table I) that the lighter $\mathrm{G} \times \mathrm{I}$ females were equal in tarsometatarsal length to $\mathrm{I} \times \mathrm{C}$ females, and slightly, but significantly, exceeded them in tarsometatarsal width.* The reciprocal $F_{1} s$ thus differ in conformation, as well as in general size, the $\mathrm{I} \times \mathrm{C}$ females being relatively plumper. Population (5) was bred partly in order to throw more light on this phenomenon. This population includes, besides reciprocal $F_{1} s$, reciprocal $F_{2} s((I \times G) \times(I \times G)$ and $(G \times I) \times$ $(\mathrm{C} \times \mathrm{I}))$, which serve the same purpose, and estimate the same effects, as the W-crosses in population (4); the male parents in either case serve merely as the source of a control set of chromosomes, and the reciprocal $F_{1}$ males should be genetically identical.

The results from population (5) are shown in tables 6 and 7 . The results for 20-week body weight are in good agreement with those from population (4), but there is a discrepancy between the shank length results and those for tarsometatarsal length in population (I). The new data show a small but highly significant $(\mathrm{P}<0 \cdot \mathrm{I}$ per cent.) difference in shank length between $F_{1}$ females. (The discrepancy might be due to the character measured not being exactly the same in the two populations, although this seems rather unlikely.) However, the important point is that this difference is proportionately smaller

\footnotetext{
* The significant interaction for tarsometatarsal width in table $I$ is entirely due to a more extreme pattern of hatch differences in I than in the other three types. When the $\mathrm{F}_{1}$ s alone are compared, the weighted mean difference, $\mathrm{I} \times \mathrm{C}-\mathrm{C} \times \mathrm{I}$, is $-0.075+0.023 \mathrm{~mm}$., and the interaction is insignificant (mean square ratio $=0.75$ ).
} 
TABLE 6

Population 5. Weighted mean differences between reciprocal crosses

\begin{tabular}{|c|c|c|c|c|}
\hline \multirow[b]{2}{*}{ Effect estimated } & \multicolumn{2}{|c|}{$\mathrm{I} \times \mathrm{C}-\mathrm{C} \times \mathrm{I}$} & \multicolumn{2}{|c|}{$(\mathrm{I} \times \mathrm{C}) \times(\mathrm{I} \times \mathrm{C}\}-(\mathrm{C} \times \mathrm{I}) \times(\mathrm{C} \times \mathrm{I})$} \\
\hline & $\stackrel{d}{M}$ & $M-\stackrel{q q}{X}+r$ & $\stackrel{\sigma^{*} \sigma^{-}}{m-X}$ & $\stackrel{+q}{+q}$ \\
\hline $\begin{array}{l}\text { Body weight at } 20 \text { weeks } \\
\text { (g.) } \\
\text { as } \% \text { of } \mathrm{C} \times \mathrm{I} \text { or }(\mathrm{C} \times \mathrm{I}) \\
\times(\mathrm{C} \times \mathrm{I})\end{array}$ & $\begin{array}{l}+107 \cdot 3 \pm 18 \cdot 5 \\
+6 \cdot 34 \pm 1 \cdot 09 \%\end{array}$ & $\begin{array}{l}+113 \cdot 0 \pm 12 \cdot 4 \\
+9 \cdot 16 \pm 1 \cdot 00 \%\end{array}$ & $\begin{array}{l}+67 \cdot 8 \pm 22 \cdot 2 \\
+4 \cdot 46 \pm 1 \cdot 46 \%\end{array}$ & $\begin{array}{l}+16 \cdot 4 \pm 14 \cdot 0 \\
+1 \cdot 39 \pm 1 \cdot 19 \%\end{array}$ \\
\hline $\begin{array}{l}\text { Shank length at } 20 \text { weeks } \\
(\mathrm{cm} .) \\
\text { as } \% \text { of } \mathrm{C} \times \mathrm{I} \text { or }(\mathrm{C} \times \mathrm{I}) \\
\times(\mathrm{C} \times \mathrm{I})\end{array}$ & $\begin{array}{l}+0.222 \pm 0.036 \\
+\mathrm{r} \cdot 98 \pm 0.32 \%\end{array}$ & $\begin{array}{l}+0.090 \pm 0.023 \\
+0.94 \pm 0.24 \%\end{array}$ & $\begin{array}{l}-0.004 \pm 0.044 \\
-0.03 \pm 0.39 \%\end{array}$ & $\begin{array}{l}+0.057 \pm 0.032 \\
+0.60 \pm 0.33 \%\end{array}$ \\
\hline $\begin{array}{l}\text { Plumpness index } \\
\text { (body weight) } /(\text { shank } \\
\text {. length) } \\
\text { as } \% \text { of } \mathrm{C} \times \mathrm{I} \text { or }(\mathrm{C} \times \mathrm{I}) \\
\times(\mathrm{C} \times \mathrm{I})\end{array}$ & $\begin{array}{l}+0.056 \pm 0.035 \\
+1.46 \pm 0.90 \%\end{array}$ & $\begin{array}{l}+0.290 \pm 0.036 \\
+6.69 \pm 0.83 \%\end{array}$ & $\begin{array}{l}+0.165 \pm 0.036 \\
+4.63 \pm 1.02 \%\end{array}$ & $\begin{array}{l}-0.000 \pm 0.039 \\
-0.002 \pm 0.93 \%\end{array}$ \\
\hline $\begin{array}{l}\text { No. hatches : } \\
\text { Total no. birds : }\end{array}$ & $\begin{array}{r}5 \\
135\end{array}$ & $\begin{array}{r}5 \\
154\end{array}$ & $\begin{array}{r}5 \\
264\end{array}$ & $\begin{array}{r}5 \\
295\end{array}$ \\
\hline
\end{tabular}

All comparisons are homogeneous between hatches, except for shank length in $F_{2}$ females (heterogeneous at 5 per cent. level.

$M, m, X$ and $Y$ as in table 5 .

The standard errors of the plumpness index are calculated according to the approximation :

$$
\operatorname{Var} \mathrm{C}=\overline{\mathrm{C}}^{2}\left[\frac{1}{\overline{\mathrm{W}}^{2}} \operatorname{Var} \mathrm{W}+\left(\frac{2 \cdot 5}{\overline{\mathrm{L}}}\right)^{2} \operatorname{Var} \mathrm{L}-\frac{5}{\overline{\mathrm{W} L}} \operatorname{Cov} \mathrm{W}, \mathrm{L}\right]
$$

where $\mathrm{C}=$ plumpness index, $\mathrm{W}=20$-week body weight and $\mathrm{L}=20$-week shank length.

TABLE 7

Estimates of the percentage effects of $M, X, m$ and $Y$

\begin{tabular}{|c|c|c|c|c|c|c|}
\hline & \multicolumn{4}{|c|}{ Direct estimates } & \multicolumn{2}{|c|}{ Assuming $m$ and $r$ zero } \\
\hline & $M$ & $x$ & $m$ & $r$ & $X(a)$ & $X(b)$ \\
\hline $\begin{array}{l}\text { Population (4) } \\
\text { 20-week body weight } \\
\text { (12-week for W-crosses) }\end{array}$ & $+5.92 \pm 0.97$ & $-3 \cdot 45$ & -0.62 & +0.37 & $-3 \cdot 08 \pm 1 \cdot 30$ & $-2 \cdot 74 \pm 0 \cdot 96$ \\
\hline $\begin{array}{l}\text { Population (5) } \\
\text { 20-week body weight } \\
\text { 20-week shank length } \\
\text { Plumpness index }\end{array}$ & $\begin{array}{l}+6.34 \pm 0.97 \\
+1.98 \pm 0.32 \\
+1.46 \pm 0.90\end{array}$ & $\begin{array}{l}-2.94 \\
+0.83 \\
-4.93\end{array}$ & $\begin{array}{l}+1.51 \\
+0.80 \\
+0.30\end{array}$ & $\begin{array}{l}-0.12 \\
-0.20 \\
-0.30\end{array}$ & $\begin{array}{l}-2 \cdot 82 \pm 1 \cdot 48 \\
+1 \cdot 04 \pm 0.40 \\
-5 \cdot 23 \pm 1 \cdot 22\end{array}$ & $\begin{array}{l}-4 \cdot 46 \pm 1 \cdot 46 \\
+0 \cdot 03 \pm 0.39 \\
-4 \cdot 63 \pm 1 \cdot 02\end{array}$ \\
\hline
\end{tabular}

(a) from $F_{1}$ males and females, (b) from $W$-cross or $F_{2}$ males. 
than that between $F_{1}$ males; a zero difference in $F_{1}$ females could arise only by chance, through opposing effects cancelling each other exactly. The estimates of $m$ and $Y$ for shank length are again not significant (although that for $m$ is rather suspiciously large), but of the two estimates of $X$ obtained by setting $m$ and $Y$ equal to zero, one is significantly positive, while the other is practically zero. The evidence for a positive value of $X$ for shank length is not conclusive, but it is strengthened by the findings on tarsometatarsal length in

TABLE 8

Hatch means calculated by the method of fitted constants

\begin{tabular}{|c|c|c|c|c|c|}
\hline Population ( 1 ) & $7^{\text {th }}$ March & 2Ist March & 2nd May & & \\
\hline Body weight at Ist egg (g.) & I 497 & 1557 & I 524 & & \\
\hline $\begin{array}{l}\text { Tarsometatarsal length } \\
(\mathrm{cm} .)\end{array}$ & $7 \cdot 735$ & $7 \cdot 873$ & $7 \cdot 975$ & & \\
\hline $\begin{array}{l}\text { Tarsometatarsal width } \\
\text { (mm.) }\end{array}$ & $6 \cdot 279$ & $6 \cdot 387$ & $6 \cdot 266$ & & \\
\hline Population (5) & $5^{\text {th }}$ March & Igth March & 2nd April & 16th April & 3oth April \\
\hline 20-week body weight (g.) & & & & & \\
\hline $\begin{array}{lll}F_{1} 0^{\circ} & : \\
F_{1}+9 & :\end{array}$ & $\begin{array}{l}\mathbf{1} 707 \\
1322\end{array}$ & $\begin{array}{l}1713 \\
\text { 1300 }\end{array}$ & $\begin{array}{l}1722 \\
\text { I } 284\end{array}$ & $\begin{array}{l}1794 \\
\text { I } 263\end{array}$ & $\begin{array}{l}\text { I } 796 \\
\text { I } 245\end{array}$ \\
\hline 20-week shank length $(\mathrm{cm}$.) & & & & & \\
\hline 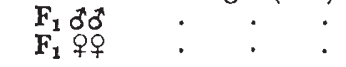 & $\begin{array}{r}11 \cdot 37 \\
9 \cdot 60\end{array}$ & $\begin{array}{r}I I \cdot 31 \\
9 \cdot 50\end{array}$ & $\begin{array}{r}11 \cdot 37 \\
9 \cdot 67\end{array}$ & $\begin{array}{r}\text { II } \cdot 7 \text { I } \\
9 \cdot 8 \mathrm{I}\end{array}$ & $\begin{array}{r}\text { II } 7 \text { I } \\
9 \cdot 75\end{array}$ \\
\hline
\end{tabular}

population (I). It is at least clear that, in contrast to $X$ for body weight, $X$ for shank length cannot have an appreciable negative value.

To measure the effects on body proportions, as distinct from general size, we may consider a third character, an index of plumpness, and regard either body weight or shank length as a secondary character, completely determined by the other two. Over the greater part of post-natal growth, shank length increases approximately as the $2 \cdot 5^{\text {th }}$ power of body weight (Lerner, 1937; Cock, 1963). Our index of plumpness may therefore take one of two forms, either of which is legitimate-a geometric form: (body weight)/(shank length) ${ }^{3}$, or an allometric form: (body weight)/(shank length) ${ }^{2 \cdot 5}$. The results for the allometric index are given in tables 6 and 7 (those for the geometric index are very similar). The results are quite clear; $M$, $m$ and $Y$ are all insignificant, while $X$ is highly significant, with the two estimates of $X$ in good agreement. Thus $M$ is primarily an effect on general size, while $X$ affects plumpness.

There is also clear evidence of hatch effects on plumpness. The 
hatch means for population (I) and for the $F_{1} s$ of population (5), obtained by the method of fitting constants, are shown in table 8 (all four series of hatch differences in population (5) are easily significant at the $\mathrm{O} \cdot \mathrm{I}$ per cent. level; significance levels for population (I) are given in table I). It is quite obvious that, in general, the hatch effects on body weight and on shank length or tarsometatarsal length do not parallel each other; nor do those for tarsometatarsal length and width. It is of interest that in population (5) the hatch means for shank length in males and females follow practically parallel trends, whereas the means for body weight do not. This suggests that the hatch effects on shank length were determined before the sexes were separated (8 weeks after hatching) and perhaps even during embryonic development, or if determined at a later age, then by factors (e.g. climatic changes) common to all birds hatched on a given date. The hatch effects on body weight, on the other hand, seem to be of a more short-term nature, and to be determined more by very local environmental conditions.

In order to check that the 20-week measurement of shank length represented the final mature shank length, the shanks of all the $F_{1}$ females in population (5) were measured again at a later date. In order to eliminate the possibility of "occasion effects" (i.e. a consistent tendency to compress the calipers more firmly against the shank on one day than on another) these second measurements were made all on the same $d . y$, at a time when the different hatches ranged between 29 and 37 weeks of age. The second measurement does show a significant, but very slight, increase in mean shank length of $0.05^{8}$ $\mathrm{cm}$.; although the increment is not equal in the different hatches (presumably because of such "occasion effects") this effect is very small, and it remains true that hatch differences in shank length do not parallel those in body weight. Most of the males were no longer available when the second measurement was taken, but the few that were measured indicate a situation similar to that found in the females. The weighted mean difference in shank length between $\mathrm{C} \times \mathrm{I}$ and $\mathrm{I} \times \mathrm{C}$ females on the basis of the second measurement is $0 \cdot 126 \pm 0.023 \mathrm{~cm}$., which does not differ significantly from the value for the first measurement.

One other incidental finding is that $\mathrm{I} \times \mathrm{C}$ and $\mathrm{C} \times \mathrm{I}$ females differ in the hæmoglobin content of their blood. Some of the birds from population ( $\mathrm{I}$ ) were used in another experiment in which parental or non-parental blood was injected into $\mathrm{F}_{1}$ females (Cork and Simonsen, 1958). The hæmoglobin level in the injected birds did not differ significantly from that in uninjected controls, but all groups contained balanced numbers of $\mathrm{I} \times \mathrm{C}$ and $\mathrm{C} \times \mathrm{I}$ females, and the difference in mean hæmoglobin content $(9 . \mathrm{I} 5 \mathrm{~g}$. per cent. in $\mathrm{I} \times \mathrm{C}$ and $8.4 \mathrm{I}$ in $\mathrm{C} \times \mathrm{I}$ ) is significant at the 2 per cent. level. (A few birds were found at autopsy to have tumours of the liver; these had abnormally low hæmoglobin values, and have been omitted from the above 
comparison.) Jaffe (1960) found a significant difference in hæmoglobin content between the parental lines $(9.9 \mathrm{~g}$. per cent. in I and $7 \cdot 2$ in $\mathrm{C} ; \mathrm{F}_{1} \mathrm{~s}$ not measured), which suggests that the reciprocal difference is due to X-chromosomal sex-linkage. Jaffe also found that the lower hæmoglobin content of $\mathrm{C}$ blood was due, in the main, to a reduced number of erythrocytes; no figures for the size or number of erythrocytes in $F_{1}$ s are available.

\section{DISCUSSION}

The most interesting question arising from these results is the mechanism of the maternal effect. The small and insignificant values obtained for $m$ indicate that it is not a case of cytoplasmic inheritance in the strict sense, transmitted indefinitely through succeeding generations, but depends rather on the nutritional environment provided for the embryo in the egg. It seems unlikely that the effect operates solely through the limitations imposed on the size of the embryo at hatching by the different egg sizes of the two lines. The work of Kosin, Abplanalp, Gutierrez and Ringrose (1952), and, by analogy, that of Walton and Hammond (1938) with mammals, suggests that the maternal effect due to the size of the egg should largely be compensated for in the first few weeks after hatching. The effect observed here is large in relation to the known difference in egg size and remains nearly constant, as a percentage, with age. A qualitative difference in the nature of the environment afforded by the egg seems a more likely source of the maternal effect. Krzanowska (1959) has found evidence of maternally determined reciprocal differences in early embryonic growth rate, at an age far too early for the embryo to be affected by the mere size of the egg. Brumby, too (1960) found evidence that maternal effects on weight in mice operated in a qualitative manner, rather than directly through maternal size. His unselected line of mice provided a maternal environment which was superior, not only to that provided by his small line, but also to that provided by his large line.

\section{SUMMARY}

Reciprocal crosses $\left(F_{1}, F_{2}\right.$ and 3-way crosses) between two inbred lines of White Leghorn, I and C, show the existence of both sexlinked and maternal effects on adult size. The smaller I line has the "larger" X-chromosome, which is responsible for an increase of about 3 per cent. in body weight as compared with the X-chromosome of the $\mathrm{C}$ line. The maternal effect of $\mathrm{C}$, as compared with that of I, produces an increase of about 6 per cent. in body weight. The maternal effect is primarily on general size, whereas the sex-linked effect alters conformation (the relation of shank length to body weight). No evidence was found of the transmission of maternal effects beyond the $\mathrm{F}_{1}$ generation, or of $\mathrm{Y}$-chromosome effects. It is unlikely that the maternal effect operates solely through egg size. 
Acknowledgments.-We are indebted to Mrs G. Shelton for permission to make use of her data on population ( $1 a$ ) ; to Mr F. J. Dudley for permission to use his data on population (3) ; to the Northern Poultry Committee of the Agricultural Research Council for their cooperation in producing and collecting data on population (4), and to Dr D. G. Gilmour for his help and encouragement.

\section{REFERENCES}

ALleN, C. P. 1962. The contribution of the plasmon to specific reciprocal cross differences in poultry. Poult. Sci., 4I, 825-839.

BRINK, J. VAN. 1959. L'expression morphologique de la digametie chez les sauropsides et les monotremes. Chromosoma, 10, I-72.

BRUMBY, P. J. 1960. The influence of the maternal environment on growth in mice. Heredity, I4, I-18.

BRUNSON, C. C., GODFREY, G. F. AND GOODMAN, B. L. 1956. Types of gene action in the inheritance of ten-week body weight and breast angle in broilers. Poult. Sci., 35, 524-532.

cock, A. G. 1953. The interpretation of autosexing. 7. Genet., 5I, $421-433$.

COCK, A. G. 1963. Genetical studies on growth and form in the fowl. I. Phenotypic variation in the relative growth pattern of shank length and body weight. Genet. Res. (in press).

COCK, A. G., AND SIMONSEN, M. 1958. Immunological attack on newborn chickens by injected adult cells. Immunology, I, I03-I IO.

EL-IBIARY, H. M., AND SHAFFNER, C. S. I951. The effect of induced hypothyroidism on the genetics of growth in the chicken. Poult. Sci., 30, 435-444.

GODFREY, E. F. 1953. The genetic control of body weight in the domestic fowl. Poult. Sci., 32, 248-259.

GOODMAN, B. L., AND GODFREY, G. F. 1956. Heritability of body weight in the domestic fowl. Poult. Sci., 35, 50-53.

GOODMAN, B. L., AND JAAP, R. G. 1960 . Improving accuracy of heritability estimates from diallel and triallel matings in poultry. 1. Eight week body weight in closed flock strains. Poult. Sci., 39, 938-944.

HALE, R. W. Ig6r. Heritabilities and genetic correlations of egg-production and other characters in a White Wyandotte flock. Anim. Prod., 3, 73-87.

HAZEL, L. N., AND LAMOREUX, W. F. 1947. Heritability, maternal effects and nicking in relation to sexual maturity and body weight in White Leghorns. Poult. Sci., 26, 508-514.

hunter, G. L. 1956. The maternal influence on size in sheep. F. Agric. Sci., $4^{8}$, 36-6o.

HURRY, H. F., AND NORDSKOG, A. W. 1953. A genetic analysis of chick feathering and its influence on growth rate. Poult. Sci., 32, 18-25.

HUT, F. в. 1959. Sex-linked dwarfism in the fowl. 7. Hered., 50, 209-221.

HUTT, F. B. 1962. The relation of broodiness to viability and to differential mortality in reciprocal crosses between Leghorns and heavy breeds. Brit. Poult. Sci., 3, 16-29.

JAFFE, P. 1960. Differences in number of erythrocytes between inbred lines of chicken. Nature, I86, 978-979.

JEROME, F. N., HENDERSON, C. R., AND KING, s. C. I956. Heritabilities, gene interactions and correlations associated with certain traits in the domestic fowl. Poult. Sci., 35, 995-1013.

JOUBERT, D. M., AND HAMMOND, J. 1958. A crossbreeding experiment with cattle, with special reference to the maternal effect in South Devon-Dexter crosses. 7. Agric. Sci., 5I, 325-34I.

Kempthorne, O. 1957. An Introduction to Genetic Statistics. John Wiley, New York. Kosin, I. L., ABPLANALP, h., GUtIERREZ, J., AND RINGrose, A. T. 1952. The influence of egg-size on subsequent early growth of the chick. Poult. Sci., $3 I, 247-254$. 
KRZANOWSKA, H. 1959. Early embryonal growth in inbred lines of Brown Leghorn and their crosses. Poult. Sci., 38, I446-1 455 .

LRRNER, I. M. 1937. Relative growth and hereditary size limitation in the domestic fowl. Hilgardia, 10, 5 I I-560.

LERNER, I. M., AND CRUDEN, D. I95I. The heritability of egg-weight ; the advantages of mass selection and of early measurements. Poult. Sci., 30, 34-4I.

MAW, A. J. G. I935. The inheritance of skeletal dimensions in the domestic fowl. Sci. Agr., I6, 85-I I 2.

MILLER, R. A. $193^{8}$. Spermatogenesis in a sex-reversed female and in normal males of the domestic fowl, Gallus domesticus. Anat. Rec., 70, I55-183.

MOULTRIE, F., KING, D. F., AND CotTieR, G. J. 1953. Influence of heterosis and maternal effects on viability in an interstrain cross of White Leghorn. Poult. Sci., 32, 935-94I.

munro, s. s. 1946. A sex-linked true-breeding blue plumage colour. Poult. Sci., $25,408-409$.

OSBORNE, R. I954. Sex-linked association of egg weight and body weight in Brown Leghorns. Proc. roy. Soc. Edin., 65, 31 7-326.

PEASE, M., AND DUdLey, F. I954. Hybrid vigour in poultry. Off. Rep. roth World's Poultry Congress, 45-49.

PEELER, R. J., GLAZENER, E. W., AND BLOW, w. L. 1955. The heritability of broiler weight and weight and age at sexual maturity and the genetic and environmental correlation between these traits. Poult. Sci., 34, 420-426.

SIEGEL, P. B. 1962. Selection for body weight at 8 weeks of age. 1. Short term response and heritabilities. Poult. Sci., 4I, 954-962.

SIEGEL, P. B., MUELleR, C. D., AND GRAIG, J. v. 1957. Some phenotypic differences among homozygous, heterozygous and hemizygous late-feathering chicks. Poult. Sci., 36, 232-239.

SNEDeCOR, G. W. I946. Statistical Methods, $4^{\text {th }}$ ed. Collegiate Press, Ames, Iowa. THOMAS, C. H., BLow, W. L., COCKERHAM, c. C., AND GLAZENER, E. W. 1958. The heritability of body weight, gain, feed consumption and feed conversion in broilers. Poult. Sci., 37, 862-869.

WAlton, A., AND hammond, J. 1938. The maternal effects on growth and conformation in Shire horse-Shetland pony crosses. Proc. Roy. Soc. B., I25, 3 I I-335. WARREN, D. C., AND MOORE, C. H. I956. Adult mortality in reciprocal crosses of Leghorns and heavy breeds. Poult. Sci., 35, I 178.

WYATT, A. J. I954. Genetic variation and covariation in egg production and other economic traits in chickens. Poult. Sci., 33, $1266-1274$.

YAo, T. S. 196r. Genetic variation in the progenies of the diallel crosses of inbred lines of chicken. Poult. Sci., 40, 1048-1059. 